\title{
The Basis, Paths and Obstacles for the Transformation of Big Enterprise Innovation to Mass Innovation in China
}

\author{
Houngneme Anicet ${ }^{1}$, Hu Yunyin ${ }^{2}$ \\ ${ }^{12}$ School Economics and Management Studies, Zhejiang University of Science and Technology (ZUST, \\ 318 liu he lu Hangzhou, Zhejiang Province: China.
}

\begin{abstract}
China is currently facing the embarrassing situation of having the world's most innovative companies on the one hand, but 99\% of the companies have not applied for patents. Under the leadership of the central government, there is an urgent need to gather the wisdom and strength of the whole society and form a joint force. Through the innovation of systems and policies, the innovation of systems and mechanisms, the innovation of cultural environment, the cultivation of talents, the innovation of SMEs, the incubation of small and micro enterprises, the leadership of industrial cluster innovation, Promote collaborative innovation of industry, university, and research institutes, stimulate grass-roots innovation, and go forward with multiple approaches and multi-pronged approaches to achieve a transformation from a large enterprise innovation society to a mass innovation society.
\end{abstract}

Keywords: Big Enterprise, SME Innovation, Patents, Paths and Obstacles, Transformation.

\section{Introduction}

A healthy and dynamic economy usually has a relatively complete system of policies to promote entrepreneurship and innovation, a relatively flexible system and mechanism, a strong atmosphere of innovation culture, and a rich reserve of innovative talents. China must seize the opportunity to comprehensively deepen reform and launch the 13th FiveYear Plan, create and improve the institutional policy environment and talent culture environment that promotes the transformation from large enterprise innovation to mass innovation, and create a world where everyone wants to innovate, everyone dares to innovate, and everyone An innovative country that can innovate and truly embark on the road of innovation-driven development.

\section{Theory driven}

Innovation is an inexhaustible driving force and important manifestation of the progress of human civilization. Since Schumpeter put forward the concept of innovation in the early 20th century, after more than a century of development, the theory of innovation has been continuously enriched and developed. Combing the development pulse of innovation theory, exploring the development trend of innovation theory, and providing the theoretical basis for the research of this article.

The system actually is shifting from closed innovation to open innovation. For most of the twentieth century, companies have always pursued that only by implementing a high degree of control over technological innovation activities can they truly realize technology confidentiality, technology exclusiveness, and technology monopoly. This model is called "closed innovation." Xerox PARC was a classic example of this innovative model. In the late twentieth century, with the continuous expansion of knowledge and technology outside the enterprise, the increasing availability of venture capital, the continuous shortening of product life cycles and the acceleration of technological updates, the continuous improvement of supplier production capabilities, and the erosion of closed innovation, The boundaries of the company are constantly being broken, internal innovation resources and activities and external innovation resources and activities frequently communicate, benign interactions and mutual benefits, and an open innovation model has gradually formed. Open innovation calls for more and more people to participate in innovation activities.

The evolution of innovation systems to the construction of innovation ecosystems. After the concept of the innovation system was proposed, there has been an upsurge in the research of industrial innovation systems and cluster innovation systems, accompanied by the deepening of the research on regional innovation systems and national innovation systems. Inspired by open innovation theoretical research and practical exploration, the concept of the innovation ecosystem was put forward. The innovation ecosystem emphasizes that the elements of innovation must evolve dynamically, hold vitality, and coexist and grow together. Mass innovation provides the source of living water for the construction of an innovation ecosystem. ${ }^{[1]}$

From the emphasis on external incubation to the overall development of internal incubation. External incubators have effectively integrated international and domestic innovation resources, absorbed high-end innovation teams, and promoted the creation and rapid development of regional enterprises.

However, external incubation is often used for emerging technology companies, and the innovation management of traditional large and medium-sized enterprises may need to tap the potential from the inside. Internal hatching theory emerges from time to time. After three stages of inorganization fertilization, in-house incubation, and in vitro

Volume 9 Issue 3, March 2020 


\section{International Journal of Science and Research (IJSR) \\ ISSN: 2319-7064}

ResearchGate Impact Factor (2018): 0.28 | SJIF (2018): 7.426

growth, a batch of subsidiaries will stand out, and the parent company will receive a huge profit return, while effectively attracting talents and supporting innovation. Internal and external incubation work together to effectively promote mass innovation. ${ }^{[2]}$

The beginning of the era of comprehensive innovation management. The innovation management practice of outstanding Japanese companies opens a new era of comprehensive innovation management: the content of innovation will no longer simply stay at the technical level, and the organization, system, culture, strategy, and market will need timely innovation; the main body of innovation will be extended to all internal and external interests of the enterprise Other service departments such as employees, suppliers, customers, competitors, and governments; innovation activities will break through the concept of time and space, and full-time, all-regional, and full-process innovation will become inevitable. In a sentence, the characteristics of the era of comprehensive innovation are innovation for everyone, innovation for everything, innovation everywhere, and constant innovation. This is also the ideal state pursued by mass innovation. ${ }^{[3]}$

\section{Call to Reality}

The 16th CPC National Congress in 2003 emphasized the importance of science and technology as the primary productive force, paying attention to relying on scientific and technological progress and improving the quality of workers, and improving the quality and efficiency of economic growth. The 2006 National Science and Technology Conference and the Seventeenth National Congress clearly proposed the establishment of an innovation system that takes enterprises as the mainstay, is market-oriented, and combines production, education, and research. The 18th National Congress of 2012 proposed the implementation of an innovation-driven development strategy, placing technological innovation at the core of national development. For more than 10 years, China has made great achievements in the fields of basic research, cutting-edge high-tech research, and applied technology research and development: the world's highest altitude and longest line on the plateau frozen soil railway opened to traffic, and the measured computing speed of the "Tianhe No. 1" supercomputer ranks first in the world I. Cold atom quantum storage technology for the first time in the world to achieve entanglement exchange with storage and readout functions, the first use of induced pluripotent stem cells (iPS cells) to clone living experimental mice, confirming that iPS cells have the same totipotency as embryonic stem cells, Independently developed 65-nanometer dielectric etcher, which is 35\% $50 \%$ higher than the world's most advanced equipment chip unit investment output,

$30 \%-35 \%$ cost reduction, TD-SCDMA and TD-LTEAdvanced technology proposals It has become an international $3 \mathrm{G}$ and $4 \mathrm{G}$ standard, and the output of international scientific papers (SCI) has risen in quantity and quality. The number of papers ranks second in the world, the number of highly cited papers ranks fourth in the world, and the number of domestic invention patent applications and authorizations ranks respectively. Ranked first and second in the world, accounting for $37.9 \%$ and $22.3 \%$ of the global total ... More gratifying is that a large number of technologybased enterprises Rapid rise, Huawei, ZTE, Aerospace Technology, Aerospace Science and Industry, Zoomlion Heavy Industry, Sany Heavy Industry, Dongfang Electric, Haier, TCL, Geely, BYD, Lenovo, SMIC ... not only promote "Made in China" to "China "Creation", and going abroad, let China's wisdom illuminate the world. ${ }^{[4]}$

However, the more you need to stay in front of your grades, the more you need to keep a clear head. We must fully see the gaps and deficiencies in China's innovation ability and performance compared with developed countries in the world: The National Innovation Index Report 2013 released by the China Academy of Science and Technology Development Strategy shows that China's comprehensive innovation ability (self-evaluation) world No. 19, has not yet entered the world's first echelon. ${ }^{[5]}$ At the same time, the National Innovation Blue Book: China Innovation Development Report (2014), co-organized by the Technology Innovation Research Center of Tsinghua University and the Social Science Literature Publishing House, also pointed out the total level of tripartite patents and R \& D personnel per 1,000 people in China in 2011. The number of patents is relatively low, $6.18 \%$ and $1.95 \%$ respectively in Japan. ${ }^{[6]}$ In addition, the statistical analysis of the "Report on the Patent Activities and Economic Benefits of Industrial Enterprises Above Designated Size in China in 2012" by the Planning and Development Department of the State Intellectual Property Office shows that of the 344,000 industrial enterprises above designated size in China, only $12.2 \%$ are above designated size. Industrial enterprises applied for patents, $11.5 \%$ of industrial enterprises above the designated size were granted patents, and $17.1 \%$ of industrial enterprises above the designated size had valid patents. Moreover, the industries and regions are too concentrated. The top five industries are still electrical machinery and equipment manufacturing, general equipment manufacturing, special equipment manufacturing, computers, communications and other electronic equipment manufacturing, chemical raw materials and chemical products manufacturing. $50.7 \&$ of industrial enterprises above the authorized size of patents, Jiangsu, Zhejiang, Guangdong, Shandong, and Anhui provinces still have the most patent authorized enterprises, accounting for $59.3 \%$ of the country. On the one hand, we have companies such as ZTE Huawei with patent applications ranking among the top three in the world, but at the same time, we have to face the embarrassing situation where less than $1 \%$ of companies have applied for patents. The road is the realistic significance of this article. ${ }^{[7]}$

\section{Conversion path}

From large enterprise innovation to mass innovation, there is no successful paradigm for reference abroad. In combination with the national innovation reality of China, based on the large resources, big brands, big projects, big visions, and big platforms owned by Chinese big enterprises, the transformation path must be tightly centered and tight. 


\section{International Journal of Science and Research (IJSR) \\ ISSN: 2319-7064}

ResearchGate Impact Factor (2018): 0.28 | SJIF (2018): 7.426

Relying on large enterprises to carry out, through the aggregation, incubation, leadership, promotion, and encouragement of SMEs, innovation of small and micro enterprises, innovation of industrial clusters, innovation of production, education, research, and grassroots innovation, truly realize the innovation of the whole people, and take innovation-driven development Avenue of sustainable development.

\subsection{Gathering SME Innovation}

In China, industrial enterprises above designated size includes very large enterprises, large enterprises, mediumsized enterprises, and small enterprises. Among them, the large enterprises and large enterprises have been baptized in competition during a long development process and already have a strong sense of innovation, ability and resources. The development of medium-sized and small enterprises is usually short. Although they play a very important role in increasing employment, promoting growth, and maintaining social stability, their urgency and initiative in innovation are not enough. The focus of the current transformation work is to focus on the development and improvement of innovative capabilities of medium and small enterprises. Relying on and surrounding a group of mega-enterprises or large enterprises in the fields of computer, communication and other electronic equipment manufacturing, instrument manufacturing, pharmaceutical manufacturing, special equipment manufacturing, electrical machinery and equipment manufacturing, etc. The network path and common vision bring together a group of small and mediumsized enterprises to form an innovative satellite enterprise group through participation, exchange, transaction, collaboration, mutual assistance, and sharing, and enhance the innovation ability of small and medium-sized enterprises. [8]

\subsection{Incubation of Small and Micro Enterprises Innovation}

Encourage mega-enterprises or large enterprises to actively explore the construction of various forms of internal incubators, encourage employees to provide innovative opinions, internal expert groups of corporate organizations evaluate and screen these innovative opinions, and provide angel investment and management assistance for entrepreneurial practices of those excellent innovative opinions.

Employee status is still reserved for entrepreneurs, and even if the business fails, they can still return to the original company and relieve their worries. As the employee company gradually grows, it gradually separates from the original enterprise and becomes a completely independent enterprise. There is only a share relationship link between it and the original enterprise. Through the operation of this incubation mechanism that encourages innovation, supports innovation, and rewards innovation, those giant companies will breed a large number of innovative small and micro enterprises, and help and support these small and micro enterprises to grow and become new giant enterprises. Big Mac companies will also follow this internal incubation mechanism to breed new second and third generation small and micro enterprises. Life, two, two, three and three things, the whole society will benefit from this fission of geometric progression. ${ }^{[9]}$

\subsection{Leading Innovation in Industrial Clusters}

There are many well-known industrial clusters in China's coastal and inland areas, either because of historical factors, or because of the attraction of regional governments, or because of their location advantages, they gather in some specific spaces to produce specialized products with advantages or characteristics, and divide labor among themselves. Cooperation and mutual cooperation form a relatively complete industrial chain. Facing the opportunities and challenges brought by the international industrial transfer, the impact of the new industrial revolutions such as the green and low-carbon economy, the blue ocean economy, and the Internet economy, as well as the resource and energy and labor dividends are slowly fading, and some of them are beginning to get lost. Some are in dire straits and urgently need transformation and upgrading. Someone needs to stand up and lead them to transform from industrial clusters to innovation clusters. This person is often the core and leading enterprise in these industrial clusters. They shoulder the mission of continuously promoting the industry to the highend development of the value chain, are good at grasping the industrial development trends in time, are brave to meet the opportunities and challenges brought by the international industrial transfer, strive to find and take the lead in breaking the path lock of the development of industrial clusters, and lead the enterprises within the cluster. "Match pairings, wrench the wrist", explore the integration of technology and economy with higher quality, create new heights of regional innovation, and lead and promote regional innovation. ${ }^{[10]}$

\subsection{Promote Industry-University Collaborative Research and Innovation}

Industry-University-Research cooperation innovation is not a new topic. However, the depth and breadth of industryuniversity-research integration in many places in China is currently not ideal. To solve the trust, financial, and model dilemmas in the collaborative innovation of industryuniversity-research collaboration and improve the level of collaborative innovation of industry-university-research collaboration, it is necessary to give full play to the role of enterprises, especially large enterprises, in technological innovation. Large enterprises are usually leading enterprises and core enterprises in some industries or regions. Compared with other SMEs, they usually have richer innovation resources, have a stronger sense of innovation, form stronger innovation capabilities, and shoulder heavier innovations. Responsibility, encountering more complex innovation challenges. Therefore, large enterprises must not only base themselves on the actual needs of the technical problems that plague current production, but also focus on cutting-edge technology in the industry, seize the current opportunities for the transformation and development of higher education in China, and meet the needs of local undergraduate institutions to build application-oriented universities. Scientific research institutions jointly carry out the construction of high-level $\mathrm{R}$

\section{Volume 9 Issue 3, March 2020}




\section{International Journal of Science and Research (IJSR) \\ ISSN: 2319-7064}

ResearchGate Impact Factor (2018): 0.28 | SJIF (2018): 7.426

\& D platforms, key industrial technology research, the undertaking of major national scientific research projects, and the establishment of high-tech enterprises. Constantly innovate the method of collaborative innovation of industry, university, research, and research, continue to cultivate the characteristics of collaborative innovation, and continue to deepen the level of collaborative innovation of industry, university, and research. Deepen the cooperation between campus and industrialization and the industrialization of scientific and technological achievements. ${ }^{[11]}$

\subsection{Stimulate Grassroots Innovation}

Last but not least, it is inspiring and motivating grassroots innovation. Grassroots wisdom is an important nourishment for China's innovation and development. We often find that many ideas of technological innovation, system innovation, and management innovation at the macro, meso, and micro levels come from the grass roots. We must respect grassroots wisdom and inspire grass-roots innovation. Large enterprises need to cooperate with the government to do a good job in institutional design to promote grassroots entrepreneurship and innovation, because they know more about the various needs of entrepreneurial innovation at the beginning than the government. At the same time, we must devote sufficient funds to create the entrepreneurial dream fund, which really supports grassroots entrepreneurship and innovation and makes up for the lack of government financial resources.

In addition, large companies can also actively use various media to continue their own series of entrepreneurial innovation stories. This is not only a publicity of their own image, but also can inspire and motivate countless grassroots innovation enthusiasm; hold various entrepreneurial innovation courses regularly and irregularly Coach training and problem solving to help and guide grassroots innovation. Make full use of Internet resources, create various open innovation virtual communities, find and gather new forces for entrepreneurial innovation, start direct dialogues on entrepreneurial innovation, and improve entrepreneurial innovation concepts and solutions in fierce ideological collisions. ${ }^{[12]}$

Through the above transformation path design, we strive to achieve an organic system of national innovation that runs through the entire economic chain, with large enterprise innovation as the leader, SME innovation as the main body, industry-university-research innovation as the pillar, small and micro-enterprises innovation, and grassroots innovation as the cornerstones. As shown in Figure 1:

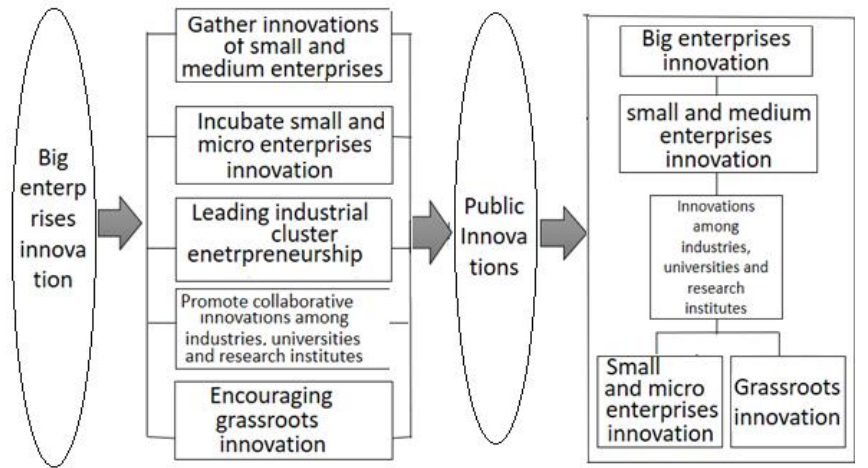

Figure 1: Roadmap for the transformation of large enterprise innovation to mass innovation

\section{Obstacles and breakthroughs}

As mentioned above, to realize the transformation from large enterprise innovation to mass innovation requires us to make a fuss around and rely on large enterprises, but this transformation cannot be achieved by the power of large enterprises alone. As Edmund Phelps, a professor at Columbia University, the 2006 Nobel Laureate in Economics, said, to promote large-scale mass innovation, China will face four major challenges: institutional policies, institutions, culture, and talent. ${ }^{[13]}$ There is an urgent need to gather the wisdom and strength of the whole society under the leadership of governments at all levels to form a joint force, work together to break through obstacles, and successfully transform.

Comprehensively deepen the reform of the economic system. Seize the opportunity of China's current comprehensive deepening reform, comprehensively sort out, and accelerate the improvement of fiscal and taxation, investment and financing systems, risk investment systems, and innovation that promote the innovation and development of SMEs, the establishment and development of small and micro enterprises, the collaborative development of production, education, and research, and grassroots entrepreneurial development Insurance system, government procurement system, intellectual property protection, equity incentives, etc. Explore the establishment of a unified and systematic tax-preferential system combining industry-based tax base reductions, tax reductions, and preferential tax rates to encourage SMEs to increase investment in research and development. Continuously improve the risk investment system and independent innovation insurance system for high-tech enterprises and small and medium-sized enterprises, accelerate the development of science and technology and finance, and strive to build a group of distinctive and influential technology insurance companies, technology banks, and small and micro-enterprises financial supermarkets to focus on knowledge Financial products such as property rights pledge financing and intellectual property trusts that serve SMEs and small and micro enterprises to start and innovate. Actively introduce credit rating agencies and credit reporting agencies to accelerate the construction of credit systems for entrepreneurial and innovative small and medium-sized enterprises and small and micro enterprises. Do everything possible to solve the problem of "knowledge and no assets" in the innovation and

Volume 9 Issue 3, March 2020 


\section{International Journal of Science and Research (IJSR) \\ ISSN: 2319-7064}

ResearchGate Impact Factor (2018): 0.28 | SJIF (2018): 7.426

development of SMEs and small and micro enterprises. Reform and improve the system and policy of government procurement of independent innovation products, continuously revise the catalog of government procurement of independent innovation products, appropriately increase the proportion of government-purchased independent innovation products or services in GDP, and give full play to the important role of government procurement in promoting technological innovation. Continuously strengthen the guiding function of national industrial technology policies, timely introduce major national industrial policies, promptly introduce the national industrial structure adjustment guidance catalog, effectively guide industrial technology research and development, realize industrial technology upgrades, and promote industrial structure optimization. ${ }^{[14]}$

Accelerate the innovation of scientific and technological mechanisms. Seize the opportunity of the central to local intensive launch of the 13th Five-Year Plan to impact the 2020 goals, and accelerate the innovation of the science and technology innovation driving mechanism, the science and technology innovation transmission mechanism, the science and technology innovation coordination mechanism, the science and technology investment and financing mechanism, and the science and technology achievements transformation mechanism. Adhere to market pressure as the primary driving force for innovation, further streamline the relationship between the government and the market, further simplify administration and decentralization, and give full play to the market's guiding role in technological

research and development direction, route selection, factor prices, and innovation factor allocation; be brave enough to break through the current fiscal and taxation system Industrial project dependence, land finance dependence, low factor cost dependence, and external technology and market dependence, completely changing the traditional industry factor-driven development model, establishing an innovation-driven development model at a higher level, and building and improving a government-driven and marketpressure dual-driven model Innovation motivation mechanism. Strengthen national to local level industrial planning and scientific and technological planning, deploy innovation chains around the industrial chain, and lead scientific and technological innovation at all levels; improve the support mechanism of governments at all levels for basic, strategic, cutting-edge scientific issues and common technology research, and serve regional entrepreneurship Innovate; formulate and implement roadmap plans to promote SME innovation and small and micro-enterprise entrepreneurship, increase the cultivation and cultivation of enterprises in the seed and start-up stages, and help them grow and develop; further explore the collaborative innovation mechanism of industry, university, and research to eliminate technological innovation The "island phenomenon" in China; actively develop the technology market, improve the mechanism for transferring scientific and technological achievements, and expand the path for transferring innovative achievements. Strengthen research and supervision of the incentive mechanism for scientific and technological innovation, and timely correct policy deviations.
Cultivate a cultural atmosphere conducive to entrepreneurship and innovation throughout society. In order to achieve the transformation from large-scale enterprise innovation to large-scale mass innovation and follow the road of entrepreneurship, enrichment, and innovation in counties (cities, provinces, and states), it is necessary to use various communication channels, integrate various communication resources, and comprehensively and threedimensionally publicize and Cultivate a culture of entrepreneurship and innovation that respects knowledge, respects creativity, values innovation, dares to take risks, and tolerates failure, changes the long-established officialmindedness of Chinese society, and adheres to the norms of small and rich, and changes the attitude of young people who want to test civil servants. Normal social phenomenon. Create a relaxed entrepreneurial and innovative culture atmosphere. Emphasis will be placed on increasing the entrepreneurial and creative will of returnees studying abroad, graduates of domestic colleges and technical secondary schools, corporate diversions and surplus workers, and landless farmers in the process of urbanization, and blowing the charge of innovation for the Chinese nation.

Seize the great opportunity of local universities and colleges to build application-oriented universities and transform and develop higher education, start by transforming the cultivation of contemporary college students, learn from the experience of entrepreneurial universities and applied technology universities in western developed countries, and base them on the actual development of local industries Based on the needs of local economic and social development, take school-enterprise cooperation, and integration of production and education as the means to build a practical and innovative ability training system and evaluation index system integrating experimental teaching, extracurricular scientific and technological innovation, and social entrepreneurship practice training, and effectively improve This new force of entrepreneurship and innovation in the future, the main force's entrepreneurship and innovation capabilities, affects and drives the overall promotion of the entire society's entrepreneurship and innovation capabilities.

\section{Conclusion}

Through theoretical deduction and statistical analysis of actual research, it is concluded that the urgent task facing China's national innovation system at present is to realize the transformation from large enterprise innovation to mass innovation as soon as possible. However, this process is affected by lagging institutional policies, institutional mechanisms, traditional culture, and limited innovation capabilities. The article proposes a multi-pronged transformation path and a countermeasure system to accelerate the transformation from the perspective of large enterprises. Future research will focus on specific path measures and deepening countermeasures on the one hand, 


\section{International Journal of Science and Research (IJSR) \\ ISSN: 2319-7064}

ResearchGate Impact Factor (2018): 0.28 | SJIF (2018): 7.426

and will focus on the construction of a quantifiable largescale mass innovation social evaluation index system.

\section{References}

[1] Zeng Guoping, etc. From "Innovation System" to "Innovation Ecosystem" [J] Science Research, 2013,01 (1): 4-12.

[2] Zhu Jin, Xuan Guoliang. Internal Incubation Mode of Enterprise for Innovation Management [J] Research and Development Management, 2001, 12 (6): 40-45.

[3] Xu Qingrui, et al. Comprehensive innovation management: a preliminary exploration of a new paradigm of innovation management-theoretical tracing and framework $[\mathrm{J}]$ Chinese Journal of Management, 2006, 03 (3): 135-142.

[4] Zhao Yongxin, et al. Ten years of innovation, Chinese isdom [EB / OL] http://politics.people.com.cn/n/2012/0723/c100118571930.html

[5] China Academy of Science and Technology Development Strategy. National Innovation Index Report [EB / $\quad$ OL] http://baike.baidu.com/view/13155314.htm\#. 22014, 03, 31.

[6] Ding Dong. "National Innovation Blue Book: China Innovation Development Report (2014)" released. [EB / OL]http://www.cssn.cn/dzyx/dzyx_jlyhz/201408/t20140 830_1310286.shtml

[7] Department of Planning and Development, State Intellectual Property Office. "Report on Patent Activities and Economic Benefits of Industrial Enterprises Above Designated Size in China in 2012" [DB / OL] http://www.sipo.gov.cn/tjxx/yjcg/gyqyzlhdyjjxyzkbg. pdf.2013,12.

[8] Meng Yan. Germany's Strategic Orientation, Architecture and Enlightenment to Support SME Innovation. [J] Reference for Economic Research, 2014, 05 (5): 78-84.

[9] Wu Yan, Shen Zhongqin. Research on the construction of technological innovation platform for small and micro enterprises. [J] Science and Technology Progress and Policy. 2014, 02 (3): 84-87.

[10] Wang Jing. A feasible path for the integration and development of industrial clusters and regional innovations. [J] Science and Technology Progress and Countermeasures 2009, 11 (22): 83-86.

[11] He Yubing. Theoretical Model of Industry-UniversityResearch Collaborative Innovation. [J] Science Research 2012,02 (2): 43-48.

[12] Lu Tian'e. Grassroots Innovative Design and Sustainable Society. [J] Anhui Agricultural Sciences 2013, 01 (1): 452-455.

[13] Edmond Phelps. How China Promotes Mass Innovation at Mass [N] Entrepreneur Daily, April 12, 2014.

[14]Feng Xiaoqing. National Industrial Technology Policy, Technology Innovation System and Industrial Technology Innovation Strategic Alliance, Contemporary Economic Management, 2011, 08 (8): 19-28. 